\title{
Association between changes in body fat distribution, biochemical profile, time of HIV diagnosis, and antiretroviral treatment in adults living with and without virus infection
}

\author{
(iD) Lismeia Raimundo Soares ${ }^{1,2}$ \\ (iD) Gabriella Coelho Menezes ${ }^{3}$ \\ (iD) Ana Paula Menna Barreto ${ }^{4}$ \\ Dônica de Souza Lima Sant'Anna ${ }^{5}$ \\ (iD) Nadir Machado Alves Cardoso ${ }^{6}$ \\ (iD) Jorge Simão do Rosário Casseb ${ }^{7,8}$ \\ (iD) Fernando Luiz Affonso Fonseca ${ }^{9}$
}

\begin{abstract}
1. Departamento de Nutrição, Programa de Nutrição Clínica, Professora na UFRJaneiro - Campus Macaé, Macaé, RJ, Brasil. 2. Doutora na Linha de Pesquisa Clínica na FMABC, Santo André, SP, Brasil. 3. Departamento de Nutrição, Nutricionista Graduada na UFRJ - Campus Macaé, Macaé, RJ, Brasil. 4. Departamento de Nutrição, Programa de Nutrição Clínica, Doutora e Professora Adjunto na UFRJ - Campus Macaé, Macaé, RJ, Brasil. 5. Departamento de Nutrição, Programa de Alimentação Coletiva, Doutora e Professora Adjunto na UFRJ - Campus Macaé, Macaé, RJ, Brasil. 6. Departamento de Vigilância, Prevenção e Controle das IST, do HIV/AIDS e das Hepatites Virais, Doutora e Farmacêutica no Programa CTA/SAE do Município de Macaé, Macaé, RJ, Brasil. 7. Professor e Doutor do Ambulatório de Imunodeficiências Secundárias. Departamento de Dermatologia. Faculdade de Medicina da USP, São Paulo, SP, Brasil. 8. Instituto de Medicina Tropical de São Paulo, Faculdade de Medicina da USP, São Paulo, SP, Brasil. 9. Professor e Doutor no Departamento de Ciências Farmacêuticas da Unifesp - Campus Diadema, Diadema, SP, Brasil, Departamento de Patologia e Análises Clínicas, Programa de Pós-graduação em Ciências da Saúde da FMABC, Santo André, SP, Brasil.
\end{abstract}

http://dx.doi.org/10.1590/1806-9282.66.1.67

\section{SUMMARY}

OBJECTIVES: Individuals living with HIV seem to be more prone to changes in the redistribution of body fat, characterized as lipodystrophy, which may occur in conjunction with metabolic diseases. In the present study, such impacts were assessed in adults with and without HIV and associated with the time of virus diagnosis and treatment with antiretroviral.

METHODS: A cross-sectional study with 123 adults, in which 87 had HIV and 36 without HIV, of both sexes, in outpatient follow-up at the Specialized Care Service (SAE) in Macaé-RJ. The following were made: 1) Alteration in body fat distribution, measured by anthropometric parameters and self-reported lipodystrophy; 2) Biochemical profile; 3) Association between HIV diagnosis time and antiretroviral treatment.

RESULTS: $54.47 \%(n=67)$ males, $45.52 \%(n=56)$ females, mean age 37 years. Of these 87 were people living with HIV, 29\% $(n=25)$ had self-reported lipodystrophy, mean time of virus infection, and antiretroviral treatment ( $5.80 \pm 4.56$ and $5.14 \pm 3.82$ years), respectively. Patients with self-reported lipodystrophy had a greater change in body fat distribution between 3-6 years of HIV diagnosis and a negative cholesterol profile. The antiretroviral treatment time influenced total cholesterol and triglycerides, even for patients without self-reported lipodystrophy, with a further nine years under treatment.

CONCLUSION: In this study, the negative cholesterol profile was mainly related to antiretroviral treatment time, even for patients without self-reported lipodystrophy, and changes in body fat distribution, measured by anthropometry, was especially associated with time for HIV infection in those with lipodystrophy self-reported.

KEYWORDS: Lipodystrophy; Profile Biochemistry; HIV.

DATE OF SUBMISSION: 22-Jul-2019

DATE OF ACCEPTANCE: 31-Aug-2019

CORRESPONDING AUTHOR: Lismeia Soares

Av. Aluizio da Silva Gomes, 50, Novo Cavaleiros, Macaé, RJ, Brasil - CEP 27930-560

Tel: 5522981559882

E-mail: lismeia@gmail.com 


\section{INTRODUCTION}

Globally, there are 21.7 million people living with HIV (PVHIV) and undergoing antiretroviral treatment (ARVT). Recently, Unaids (2018) ${ }^{1}$ stated that the efficient way to control the HIV/Aids epidemic must be the universal treatment of all infected individuals. However, this must be individualized, avoiding adverse effects in the long term.

The use of antiretroviral therapy has increased life expectancy by up to 37 years in HIV-infected patients, although changes in the redistribution of body fat, characterized as lipodystrophy, can lead to serious health problems, especially for individuals with an accumulation of visceral fat, which may happen with or without metabolic changes ${ }^{2}$.

The world literature has not yet reached a consensus on the specific criteria and predictive models for the diagnosis of lipodystrophy in HIV-infected patients. The clinical signs observed can be confirmed by anthropometric measures, radiological or imaging exams, or through an evaluation of the subjective symptoms reported by patients conducted by the health team that follows them up, or a combination of these. ${ }^{3}$

Thus, the present study aimed to check for changes in body fat distribution among individuals living with and without HIV and establish an association between self-reported lipodystrophy (SL), duration of HIV infection (THIV), and treatment with antiretroviral therapy (TTO) in those infected by the virus.

\section{METHODS}

This was a cross-sectional study with 123 adults of both sexes, aged between 18 and 59 years, of which 87 were infected with HIV and 36 were not, treated at the outpatient clinic of the Specialized Care Service (SAE) of the STI/AIDS and Viral Hepatitis Program, in the municipality of Macaé - RJ, Brasil. The data collection happened between July 2016 and February 2017, and the exclusion criteria were: pregnant women, children, adolescents, elderly individuals, and those with a previous diagnosis of cardiovascular disease (CVD).

All volunteers were informed about the study and signed a Free and Informed Consent Form (ICF), which was approved by the research ethics committee of UFRJ - Macaé Campus under CAAE: 55102516.0,0000.5699, under which this study is part of a larger project which is still in progress.

The criteria used to assess self-reported lipodystrophy (SL) was the patient's perception of changes regarding the redistribution of body fat after the HUV diagnosis, based on the "Smart Study"4 and a tool used in the study by Soares ${ }^{5}$. We also used different anthropometric parameters to measure the distribution of body fat, which was characterized by the fat and/or muscle mass loss in the upper and/or lower limbs (lipoatrophy), the accumulation of fat in the central region of the body (lipohypertrophy), and the combination of both (mixed lipodystrophy), in accordance with Guidelines for Managing HIV in Adults.

For the biochemical profile, we considered: total cholesterol (TC), triglycerides (TG), HDL-cholesterol, LDL-cholesterol, according to Faludi et al. ${ }^{7}$, fasting glycemia, per the Brazilian Society of Diabetes ${ }^{8}$, TCD4 lymphocyte count, and viral load ${ }^{6}$.

The Body Mass Index (BMI) was determined according to the $\mathrm{WHO}^{9}$, the waist perimeter (WP) according to the $\mathrm{NIH}^{10}$, as recommended by the Guidelines for HIV in Adults ${ }^{6}$ and the waist/height ratio (WHR) based on Ashwell e Hsieh ${ }^{11}$. For the neck perimeter (NP) we considered the cutoff point of $\geq 39.5 \mathrm{~cm}$ for men and $\geq 36.5 \mathrm{~cm}$ for women as excess weight, per Ben-Noun And Laor ${ }^{12}$. The body fat (BF) was assessed in kilogram $(\mathrm{kg})$, and the cutoff point for the body fat index (BFATI) had its cut-off point in percentiles between 5.5-8.3 for women and 4.0-5.7 for men, per Schutz et al. ${ }^{13}$, and the percentage of body fat (BF\%) was measured according to Durnin and Womersley ${ }^{14}$, by the sum of skinfolds, in which the anatomical points, the technique, and classification were obtained based on the recommendations by Lohman $^{15}$. The triceps skinfold (TSF) was measured with the aid of an adipometer of the Cescorf Innovare $^{\circledR}$ brand, Curitiba - PR, Brasil, three times; the cutoff point for eutrophy was 10.0-11.5 mm for men, and 18.5-26.0 $\mathrm{mm}$ for women, per Frisancho ${ }^{16}$. The arm perimeter (AP) for males was $30.7-32.3 \mathrm{~cm}$ and 26.9-30.9 $\mathrm{cm}$ for females ${ }^{16}$; the corrected arm-muscle area (AMAc) was 49.4-54.0 and 28.3-34.7 cm, respectively, for both genders ${ }^{216}$. We obtained the lean mass (LBM) in kilogram (kg), and the skeletal muscle mass (SMM) in kg was determined using the equation proposed by Lee et al. ${ }^{17}$.

To analyze the variables based on sex, we used the Student's t-test to assess variables with normal distribution; for those that did not present normal distribution, we used the Mann-Whitney test. To compare the groups with TTO and THIV, Anova was used. In all analyses, we considered a significance level of $5 \%$ in the SPSS software, version 19. 


\section{RESULTS}

We included 123 people living with and without HIV, $54.47 \%(\mathrm{n}=67)$ males, and $45.52 \%(\mathrm{n}=56)$ females, with an average age of $37.5 \pm 10.58$ years. Among these, 87 were infected by the virus, with an average time of HIV diagnosis (THIV) and treatment with antiretroviral therapy (TTO) of, respectively, $5.80 \pm 4.56$ and $5.14 \pm 3.82$ years. They had been under $20 \%(n=25)$ ARVT for over 10 years, $70 \%$ already exposed to some type of regimen using a protease inhibitor (PI), with an undetectable viral load ( $<50$ copies $/ \mathrm{mL})$ in $80 \%(\mathrm{n}=63)$, TCD4 counts $\left(\geq 350\right.$ cells $\left./ \mathrm{mm}^{3}\right)$ at $95 \%(\mathrm{n}=73)$ and $(\leq 200$ cells $\left./ \mathrm{mm}^{3}\right)$ in $15 \%(\mathrm{n}=4)$, demonstrating good adherence to antiretroviral therapy.

In the interview, $28.73 \%(\mathrm{n}=25)$ reported changes in body fat distribution perceived after the HIV diagnosis, characterizing reported lipodystrophy (RL); $18.39 \%$ $(\mathrm{n}=16)$ denied that, and $34.48 \%(\mathrm{n}=30)$ were not able to answer and/or ignored the question. Among women, $64 \%(n=16)$ reported RL, noting especially central lipo-hypertrophy in 52\% ( $\mathrm{n}=13)$ and $40 \%$ of mixed lipodystrophy $(\mathrm{n}=10)$. Among men, 36\% $(\mathrm{n}=9)$ confirmed $\mathrm{RL}$, with frequency of $44.4 \%(\mathrm{n}=4)$ of lipo-hypertrophy, $66.6 \%(\mathrm{n}=6)$ of mixed lipodystrophy, and $77.7 \%(\mathrm{n}=7)$ of lipoatrophy (Figure 1).

In Table 1, per BMI, we can see eutrophia for men with HIV and pre-obesity for the other participants. The BF\% ranked men without HIV with obesity ( $p=0.001)$ and women, regardless of HIV, ranked above average, with a significantly higher value for those without HIV ( $p=0.032)$. Men with HIV showed a significantly greater loss of $\mathrm{BF}(\mathrm{p}=0.001)$; LBM $(\mathrm{p}=0.010)$;
$\operatorname{SMM}(\mathrm{p}=0.001)$; TSF $(\mathrm{p}=0.001)$ and BP $(\mathrm{p}=0.022)$, compared to those without HIV, characterizing a loss of body fat, musculoskeletal, indicative of mixed lipodystrophy. For women with HIV, the significant TSF loss of body fat in the upper limbs $(p=0.024)$ stood out, indicating the presence of lipoatrophy. The WHR and WP parameters indicated fat accumulation in the central region in all women, regardless of HIV. However, for men, we found significant values for WHR $(\mathrm{p}=0.008)$ and WP $(\mathrm{p}=0.037)$ in individuals without HIV, indicating that, among them, the excess weight seems to be directly correlated to higher risks due to the accumulation of fat in the abdominal region (lipohypertrophy), according to these parameters.

In Table 2, the results characterized a greater change in the behavior of body fat distribution for people infected with HIV for 3-6 years and with self-reported lipodystrophy, measured by BMI, WP, and AMAc; the cholesterol profile was negative, based

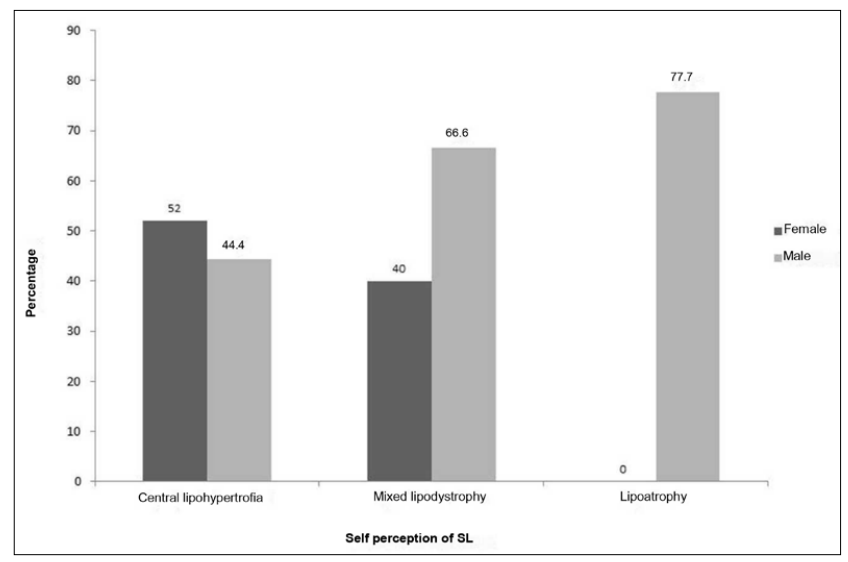

FIGURE 1

TABLE 1. CHANGES IN BODY FAT DISTRIBUTION ACCORDING TO ANTHROPOMETRIC PARAMETERS IN MEN AND WOMEN LIVING WITH AND WITHOUT HIV, ASSISTED BY THE SAE/STI/AIDS IN MACAÉ - RJ, 2018

\begin{tabular}{|c|c|c|c|c|c|c|}
\hline \multirow[t]{2}{*}{ VARIABLES } & \multicolumn{3}{|c|}{ WOMEN } & \multicolumn{3}{|c|}{ MEN } \\
\hline & $\begin{array}{l}\text { With HIV } \\
(\text { Mean } \pm \text { SD) }\end{array}$ & $\begin{array}{l}\text { Without HIV } \\
\text { (Mean } \pm \text { SD) }\end{array}$ & P-value & $\begin{array}{l}\text { With HIV } \\
(\text { Mean } \pm \text { SD) }\end{array}$ & $\begin{array}{l}\text { Without HIV } \\
\text { (Mean } \pm \text { SD) }\end{array}$ & P-value \\
\hline $\mathrm{BMI}$ & $27.91 \pm 7.08$ & $28.50 \pm 5.35$ & 0.733 & $23.94 \pm 4.26$ & $29.30 \pm 6.44$ & $0.001^{\star *}$ \\
\hline $\mathrm{BF} \%$ & $25.66 \pm 4.12$ & $27.93 \pm 3.64$ & $0.032^{*}$ & $23.37 \pm 5.19$ & $28.65 \pm 3.92$ & $0.001^{*}$ \\
\hline $\mathrm{BF}$ & $18.85 \pm 7.35$ & $20.95 \pm 6.10$ & 0.252 & $16.97 \pm 6.20$ & $25.79 \pm 8.16$ & $<0.001^{\star}$ \\
\hline LBM (kg) & $49.61 \pm 12.37$ & $52.68 \pm 9.08$ & 0.302 & $54.54 \pm 9.23$ & $62.58 \pm 10.98$ & $0.010^{*}$ \\
\hline BFATI & $7.08 \pm 2.61$ & $8.10 \pm 2.30$ & 0.125 & $5.68 \pm 2.02$ & $8.58 \pm 2.83$ & $<0.001^{\star \star}$ \\
\hline SMM (kg) & $21.21 \pm 9.38$ & $22.31 \pm 3.20$ & 0.595 & $28.42 \pm 4.24$ & $33.30 \pm 3.89$ & $<0.001^{\star \star}$ \\
\hline WHR & $0.54 \pm 0.08$ & $0.55 \pm 0.07$ & 0.796 & $0.48 \pm 0.09$ & $0.57 \pm 0.13$ & $0.008^{*}$ \\
\hline WP & $86.88 \pm 13.95$ & $88.80 \pm 12.29$ & 0.573 & $85.14 \pm 10.33$ & $99.27 \pm 21.25$ & $0.037^{\star}$ \\
\hline TSF (mm) & $19.89 \pm 9.27$ & $25.07 \pm 7.41$ & $0.024^{*}$ & $16.11 \pm 9.02$ & $26.90 \pm 10.43$ & $0.001^{*}$ \\
\hline $\mathrm{AP}(\mathrm{cm})$ & $30.30 \pm 5.77$ & $31.67 \pm 4.99$ & 0.341 & $29.35 \pm 3.89$ & $32.36 \pm 4.57$ & $0.022^{\star}$ \\
\hline
\end{tabular}

Note: $\mathrm{BMI}=$ body mass index; $\mathrm{BF}=$ body fat; $\mathrm{BF} \%$ = body fat \% by skinfold addition; $\mathrm{LBM}=$ lean body mass; $\mathrm{BFATI}=$ body fat adjusted index; $\mathrm{SMM}=$ skeletal muscle mass; $\mathrm{WHR}$

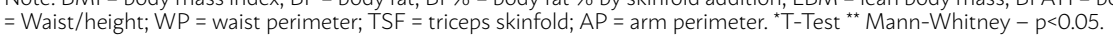


on TC and LDC-c, which also presented higher average values for those with between 3-6 years of HIV diagnosis than between $0-3$ years, characterizing that every three years of infection indicated a negative cholesterol profile for those infected who have self-reported lipodystrophy, although TC was higher among those with 6-9 years of HIV diagnosis than among those with 0-3 years. For patients without lipodystrophy, AMAc had higher values for those infected by the virus for over nine years. TC was higher among individuals with 6-9 years of HIV diagnosis. For the LDLc and TG, in individuals with more than 9 years of infection, the average values were greater than in those with $0-3$ years, indicating that even for those without lipodystrophy, the time of infection negatively influenced these biochemical parameters (TC, LDL-c, and TG).

In Table 3, the results showed that for every three years of treatment regimens (TTO), there was a trend of worsening in the lipid profile (TC, LDL-c, and TG) for people living with HIV with self-reported lipodystrophy. For those classified without self-reported lipodystrophy, the parameter that stands out is the corrected arm-muscle area (AMAc), for which those with over nine years of TTO presented higher average values than those with
0-3 years of ARVT, who already show mild impairment of muscle mass in the upper limbs, according to this parameter. In the biochemical profile, the TC and TG of individuals with over nine years of treatment presented higher average values than those with 0-3 years of ARVT, indicating that, for these parameters, the time of antiretroviral use influenced the cholesterol profile, even for patients without lipodystrophy.

\section{DISCUSSION}

In the present study, we emphasize that antiretroviral therapy promoted greater life expectancy among people infected with HIV; however, it is associated with increased body adiposity and chronicity of the inflammatory status, causing a series of endocrine-metabolic abnormalities ${ }^{\mathbf{1 8 . 1 9}}$.

There are several reports on the prevalence of lipodystrophy, ranging from $8 \%$ to $84 \%$, with an average of $42 \%$, particularly in regimens containing PI, due to differences in diagnostic criteria, selection of the study population, and duration of follow-up ${ }^{1,2,6}$. The literature indicates that patients under use PI for a minimum of 18 months were two times more likely to

TABLE 2. ASSOCIATION BETWEEN ANTHROPOMETRIC, BIOCHEMICAL PROFILE, THIV WITH AND WITHOUT SELFREPORTED PRESENCE OF LIPODYSTROPHY OF PVHIV, ASSISTED BY SAE/STI/AIDS IN MACAÉ - RJ, 2018

\begin{tabular}{|c|c|c|c|c|}
\hline \multicolumn{5}{|c|}{ Time of THIV } \\
\hline \multicolumn{5}{|c|}{ With self-reported lipodystrophy } \\
\hline & 이 - $\mid 3$ years & $3-16$ years & $6-19$ years & $>9$ years \\
\hline BMI & $23.96 \pm 3.87^{\mathbf{a}}$ & $34.48 \pm 13.37^{\mathbf{b}}$ & $23.72 \pm 2.25^{\mathbf{a}}$ & $25.72 \pm 4.35^{\mathbf{a}}$ \\
\hline WP & $86.78 \pm 11.23^{\mathbf{a}}$ & $112.60 \pm 17.15^{b}$ & $86.00 \pm 7.87^{\mathrm{a}}$ & $94.70 \pm 11.52^{\mathbf{a}, \mathbf{b}}$ \\
\hline SMM & $23.35 \pm 4.42^{\mathbf{a}}$ & $24.86 \pm 2.92^{\mathbf{a}}$ & $25.13 \pm 6.18^{a}$ & $22.36 \pm 5.65^{\mathbf{a}}$ \\
\hline AMAc & $28.72 \pm 10,64^{a}$ & $58.13 \pm 8.57^{\mathbf{b}}$ & $46.58 \pm 22.49^{a, b}$ & $39.09 \pm 11.26^{\mathbf{a}, \mathbf{b}}$ \\
\hline $\mathrm{BF} \%$ & $24.28 \pm 6.25^{\mathbf{a}}$ & $23.47 \pm 8.38^{\mathbf{a}}$ & $22.74 \pm 3.00^{\mathbf{a}}$ & $25.73 \pm 3.68^{\mathbf{a}}$ \\
\hline $\mathrm{CT}$ & $180.60 \pm 72,21^{a}$ & $268.33 \pm 54.51^{b}$ & $201.80 \pm 58.79^{\mathbf{a}, \mathbf{b}}$ & $233.00 \pm 92.37^{\mathbf{a}, \mathbf{b}}$ \\
\hline$L D L-c$ & $108.60 \pm 46,58^{a}$ & $186.33 \pm 61.80^{\mathbf{b}}$ & $134.80 \pm 40.56^{\mathbf{a}, \mathbf{b}}$ & $128.60 \pm 44.39^{a, b}$ \\
\hline TG & $151.60 \pm 67,88^{a}$ & $140.66 \pm 14,97^{a}$ & $129.00 \pm 54,1^{a}$ & $149.00 \pm 72,44^{a}$ \\
\hline GLU & $109.60 \pm 55,22^{\mathbf{a}}$ & $109.00 \pm 6,00^{\mathbf{a}}$ & $90.60 \pm 7,43^{a}$ & $100.27 \pm 26,11^{a}$ \\
\hline \multicolumn{5}{|c|}{ Without self-reported lipodystrophy } \\
\hline & 이 - $\mid 3$ years & $3-16$ years & $6-19$ years & $>9$ years \\
\hline BMI & $23.59 \pm 4.28^{a}$ & $22.50 \pm 6.23^{\mathbf{a}}$ & $25.59 \pm 2.75^{\mathbf{a}}$ & $26.98 \pm 1.60^{a}$ \\
\hline WP & $86.25 \pm 11.89^{a}$ & $85.66 \pm 16.25^{\mathbf{a}}$ & $93.37 \pm 9.79^{a}$ & $99.30 \pm 5.24^{a}$ \\
\hline SMM & $29.70 \pm 4.20^{\mathbf{a}}$ & $20.97 \pm 9.55^{\mathbf{a}}$ & $22.04 \pm 2.54^{a}$ & $22.60 \pm 5.96^{\mathbf{a}}$ \\
\hline AMAc & $25.17 \pm 4.43^{a}$ & $32.80 \pm 20.27^{\mathbf{a}}$ & $39.83 \pm 5.58^{a}$ & $44.56 \pm 8.81^{a}$ \\
\hline $\mathrm{BF} \%$ & $25.94 \pm 5.93^{\mathbf{a}}$ & $24.55 \pm 0.83^{a}$ & $26.76 \pm 6.03^{a}$ & $23.8 \pm 4.46^{a}$ \\
\hline $\mathrm{CT}$ & $183.00 \pm 34.03^{a}$ & $195.00 \pm 47.62^{\mathbf{a}, \mathbf{b}}$ & $244.25 \pm 39.73^{b}$ & $226.66 \pm 44.92^{\mathbf{a}, \mathbf{b}}$ \\
\hline LDL-c & $109.25 \pm 27.50^{a}$ & $137.00 \pm 50.21^{\mathbf{a}, \mathbf{b}}$ & $146.25 \pm 14.31^{\mathbf{a}, \mathbf{b}}$ & $158.00 \pm 50.72^{\mathbf{b}}$ \\
\hline TG & $96.00 \pm 30.88^{a}$ & $120.66 \pm 36.69^{\mathbf{a}, \mathbf{b}}$ & $181.25 \pm 227.09^{a, b}$ & $307.00 \pm 276.79^{b}$ \\
\hline GLU & $82.00 \pm 15.42^{\mathbf{a}}$ & $89.66 \pm 14.15^{a}$ & $122.00 \pm 66.19^{a}$ & $99.00 \pm 29.02^{\mathbf{a}}$ \\
\hline
\end{tabular}

Note: $\mathrm{BMI}=$ body mass index; $\mathrm{SMM}=$ skeletal muscle mass; $\mathrm{BF} \%=$ body fat $\%$ by skinfold addition; $\mathrm{WP}=$ waist perimeter; $\mathrm{AMAC}=$ corrected arm- muscle area; $\mathrm{TC}=$ total cholesterol; TG = triglycerides; LDLC = LDL cholesterol; Glu = glucose; PVHIV = people living with HIV; THIV = time of HIV infection. ${ }^{*}$ T-Test ${ }^{\star}{ }^{\star}$ Mann-Whitney $-p<0.05$. 
develop lipodystrophy, with a prevalence of lipoatrophy (33.1\%), attributed to the use of PI and the time of use of ARVT ${ }^{2.20}$.

Beraldo et al. ${ }^{21}$ found a prevalence of lipodystrophy in $47.7 \%$ of patients with HIV, among whom 53\% presented high abdominal adiposity, and more than $50 \%$ of those evaluated presented metabolic changes. In another study that included patients in a regimen with two types of protease inhibitors (PI), the mixed type of lipodystrophy was the most prevalent in $42.5 \%$ of patients, followed by lipoatrophy in $32.5 \%$, and lipohypertrophy in $25 \%{ }^{22}$. Our findings corroborate those previously been reported in the literature.

The use of anthropometric indicators is advantageous, simple, of good reliability and applicable on a large scale. Authors have shown high values of positive and significant correlation between anthropometric and image methods to measure body fat distribution in patients with HIV and concluded that the anthropometric model has advanced in the field of public health, facilitating early diagnosis and better management of lipodystrophy in patients with HIV, with precision and a diagnosis prediction of $80 \%$ in this target group ${ }^{23}$.

In this study, based on the BMI, only men with HIV were diagnosed eutrophic, and the variables of central adiposity (WHR and WP) had significantly higher values among men without HIV, while for women, regardless of HIV, these measures seemed inadequate. A Brazilian study presented the indicators of central fat (WP and WHR) as the most efficient to identify metabolic changes in HIV-infected patients ${ }^{21}$. Sacilotto et al. ${ }^{22}$ classified lipodystrophy into three subtypes according to the region of the body and metabolic changes and found that the group with lipohypertrophy presented greater changes, with higher values of total body fat per center, area of visceral fat, and BMI, compared to other groups with HIV.

In relation to BF\%, individuals without HIV, regardless of sex, were classified with higher values in our study. In addition to increased body adiposity, there is speculation that people living with HIV have a greater probability of developing accelerated aging syndrome with musculoskeletal changes (lean mass and muscle function), aging approximately 15 years early. Thus, the use of methods that can measure body fat in a segmented way in these individuals is essential ${ }^{21.22}$.

We observed, in relation to changes in body fat distribution by means of anthropometry, that men

TABLE 3. ASSOCIATION BETWEEN ANTHROPOMETRIC, BIOCHEMICAL PROFILE, TTO WITH AND WITHOUT SELFREPORTED PRESENCE OF LIPODYSTROPHY OF PVHIV, ASSISTED BY SAE/STI/AIDS IN MACAÉ - RJ, 2018

\begin{tabular}{|c|c|c|c|c|}
\hline \multicolumn{5}{|c|}{ TTO TIME } \\
\hline \multicolumn{5}{|c|}{ With self-reported lipodystrophy } \\
\hline & 이 - $\mid 3$ years & $3-16$ years & $6-19$ years & $>9$ years \\
\hline BMI & $24.84 \pm 3.56^{\mathbf{a}}$ & $31.88 \pm 12.25^{a}$ & $24.30 \pm 3.28^{a}$ & $25.34 \pm 4.84^{a}$ \\
\hline WP & $88.55 \pm 9.15^{a}$ & $103.56 \pm 17.68^{a}$ & $88.33 \pm 17.09^{a}$ & $94.02 \pm 12.42^{\mathrm{a}}$ \\
\hline SMM & $24.13 \pm 4.55^{\mathrm{a}}$ & $24.69 \pm 3.11^{a}$ & $23.63 \pm 6.48^{a}$ & $21.92 \pm 6.58^{a}$ \\
\hline AMAC & $34.31 \pm 16.96^{\mathbf{a}}$ & $48.47 \pm 14.73^{a}$ & $44.81 \pm 24.72^{\mathrm{a}}$ & $41.19 \pm 11.55^{a}$ \\
\hline $\mathrm{BF} \%$ & $24.92 \pm 5.63^{a}$ & $24.65 \pm 5.03^{a}$ & $20.81 \pm 1.58^{a}$ & $24.96 \pm 3.57^{\mathrm{a}}$ \\
\hline $\mathrm{CT}$ & $165.87 \pm 58.49^{\mathrm{a}}$ & $244.20 \pm 68.96^{\mathbf{a}, \mathbf{b}^{*}}$ & $301.66 \pm 130.19^{b^{*}}$ & $228.37 \pm 54.03^{\mathbf{a}, \mathbf{b}}$ \\
\hline LDLC & $97.87 \pm 40,55^{\mathrm{a}}$ & $163.20 \pm 64.33^{b}$ & $163.50 \pm 6.36^{b}$ & $142.00 \pm 36.64^{a, b}$ \\
\hline $\mathrm{TG}$ & $125.75 \pm 63,12^{\mathbf{a}}$ & $147.60 \pm 48.78^{\mathrm{a}, \mathrm{b}}$ & $262.00 \pm 51.18^{b}$ & $167.50 \pm 69.03^{\mathrm{a}, \mathrm{b}}$ \\
\hline GLU & $103.00 \pm 44.86^{a}$ & $104.20 \pm 7.85^{a}$ & $92.33 \pm 4.16^{a}$ & $101.11 \pm 28.72^{\mathbf{a}}$ \\
\hline \multicolumn{5}{|c|}{ Without self-reported lipodystrophy } \\
\hline & 이 - $\mid 3$ years & $3-16$ years & $6-19$ years & $>9$ years \\
\hline BMI & $22.75 \pm 4.16^{a}$ & $25.77 \pm 6.35^{\mathbf{a}}$ & $24.75 \pm 1.50^{\mathrm{a}}$ & $27.21 \pm 1.67^{a}$ \\
\hline WP & $83.60 \pm 11.88^{a}$ & $96.00 \pm 13.85^{a}$ & $91.12 \pm 7.23^{a}$ & $100.16 \pm 5.37^{a}$ \\
\hline SMM & $26.95 \pm 7.15^{a}$ & $23.25 \pm 8.50^{a}$ & $21.07 \pm 2.88^{a}$ & $24.64 \pm 3.01^{\mathrm{a}}$ \\
\hline AMAC & $25.76 \pm 4,06^{a}$ & $38.61 \pm 20.72^{a, b}$ & $36.02 \pm 5.56^{a, b}$ & $47.40 \pm 6.03^{b}$ \\
\hline $\mathrm{BF} \%$ & $25.48 \pm 5.24^{a}$ & $27.09 \pm 3.62^{a}$ & $24.86 \pm 5.30^{\mathrm{a}}$ & $23.45 \pm 4.98^{a}$ \\
\hline $\mathrm{CT}$ & $178.20 \pm 31.77^{a}$ & $228.66 \pm 45.08^{\mathbf{a}, \mathbf{b}}$ & $214.50 \pm 62.20^{a, b}$ & $243.80 \pm 17.92^{b}$ \\
\hline LDLC & $106.60 \pm 24.54^{a}$ & $149.00 \pm 38.43^{a}$ & $132.00 \pm 39.48^{a, b}$ & $178.75 \pm 23.67^{\mathbf{b}}$ \\
\hline $\mathrm{TG}$ & $96.40 \pm 26.76^{a}$ & $109.66 \pm 49.57^{\mathbf{a}, \mathbf{b}}$ & $209.25 \pm 214.55^{\mathbf{a}, \mathbf{b}}$ & $333.40 \pm 300.90^{b}$ \\
\hline GLU & $82.00 \pm 13.33^{a}$ & $93.66 \pm 12.50^{a}$ & $120.50 \pm 67.10^{a}$ & $101.20 \pm 31.88^{a}$ \\
\hline
\end{tabular}

Note: $\mathrm{BMI}=$ body mass index; $\mathrm{SMM}=$ skeletal muscle mass; $\mathrm{BF} \%=$ body fat $\%$ by skinfold addition; $\mathrm{WP}=$ waist perimeter; $\mathrm{AMAc}=$ corrected arm-muscle area; $\mathrm{TC}=$ total cho-

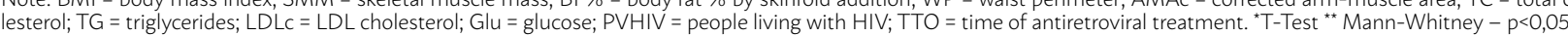


with HIV presented a significantly greater loss of body fat and musculoskeletal mass, which is indicative of mixed lipodystrophy, and $77.7 \%$ of them confirmed, based on self-perception, lipoatrophy. In females, significant loss of body fat in the upper limbs, assessed by (DCT), stood out among those infected by the virus, which is indicative of lipoatrophy. However, regarding self-reports, most of them noticed mainly lipohypertrophy, although, in both sexes, mixed lipodystrophy was frequent in self-perception. The literature points to a recent study that compares self-reported signs (lipohypertrophy/lipoatrophy) with skinfold thicknesses in 815 people living with HIV. It found mainly an increase of fat in the neck and waist and a reduction of fat in the limbs ${ }^{24}$, data similar to ours, and which demonstrate the importance of evaluating body redistribution in individuals with HIV per body segment.

In people infected by HVI, recognizing changes in body fat distribution and in the metabolic profile should be an important aspect to be addressed because the adipose tissue is an important trigger of metabolic alterations, raising the risk of morbidity and mortality, especially in patients under ARVT ${ }^{2,3,20}$. Beraldo et al. ${ }^{21}$ found a high prevalence of lipodystrophy and metabolic changes in HIV patients under antiretroviral therapy, and Marins et al. ${ }^{19}$ noticed that all people with HIV undergoing ARVT in his study presented changes in at least one type of lipid molecule in the lipid profile test, with emphasis on low levels of HDL and increased total cholesterol.

It is worth mentioning that, despite the adverse effects, ARVT is of paramount importance for the restoration of the immune system ${ }^{22}$, and despite the relevance of the subject, no studies were found that correlated TTO and THIV with the presence or absence of lipodystrophy. However, our findings indicate that the time of ARVT negatively influenced the cholesterol profile, and there was mild impairment of muscle mass, according to the AMAc, in patients without self-reported lipodystrophy. The changes in body fat distribution, measured by anthropometry, were especially associated with the duration of HIV infection in individuals with self-reported lipodystrophy. Due to the use of ARVT in the long term, the need for studies exploring the association of antiretroviral therapy with lipodystrophy and biochemical profile in people living with HIV is imperative.

\section{CONCLUSION}

The results of this study characterized changes in the behavior of the body fat distribution, known as lipodystrophy, which is associated with self-reported lipodystrophy, duration of treatment with antiretroviral drugs, and the duration of HIV infection.

\section{Contribution of the authors}

LR SOARES, GC Menezes, APM Barreto participated in the research design, data collection, data analysis, discussion, and writing of the manuscript. NMA Cardoso, MSL Sant'Anna, JSR Casseb, and FLA Fonseca participated in the intellectual design of the manuscript, data analysis, data discussion, writing, and final revision of the manuscript. All authors declare there are no conflicts of interest.

\section{RESUMO}

OBJETIVOS: Indivíduos vivendo com HIV parecem mais propensos às alterações na redistribuição da gordura corporal, caracterizada como lipodistrofia, podendo acontecer em conjunto com as metabólicas. No presente estudo avaliaram-se tais impactos em adultos com e sem HIV e se associou ao tempo de diagnóstico do vírus e tratamento com antirretroviral.

MÉTODos: Estudo tipo transversal, com 123 adultos, no qual 87 tinham HIV e 36 sem HIV, de ambos os sexos, em seguimento ambulatorial no Serviço de Atendimento Especializado (SAE) em Macaé - RJ. Foram feitos: 1) Alteração na distribuição da gordura corporal, mensurados por parâmetros antropométricos e lipodistrofia autorreferida; 2) Perfil bioquímico; 3) Associação entre tempo diagnóstico do HIV e tratamento com antirretroviral.

RESULTADOS: Incluíram-se 54,47\% (n=67) do sexo masculino, 45,52\% ( $n=56$ ) do feminino, com média de idade de 37 anos. Destes, 87 eram pessoas vivendo com HIV, 29\% (n=25) possuíam lipodistrofia autorreferida; tempo médio de infecção pelo vírus e tratamento

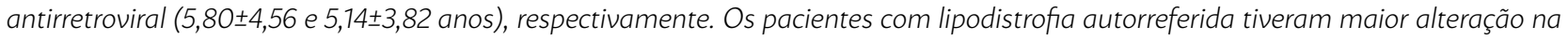
distribuição da gordura corporal entre 3-6 anos de diagnóstico do HIV e um perfil colesterolêmico negativo. O tempo de tratamento com antirretroviral influenciou o colesterol total e os triglicerídeos, mesmo para os pacientes sem lipodistrofia autorreferida, com mais de nove anos sob tratamento.

CONCLUSÃo: Neste estudo, o perfil colesterolêmico negativo se relacionou principalmente ao tempo de tratamento com antirretroviral, mesmo para os pacientes sem lipodistrofia autorreferida e as alterações na distribuição da gordura corporal, mensuradas por antropometria, se associaram especialmente ao tempo de infecção pelo HIV naqueles com lipodistrofia autorreferida.

palaVRas-ChaVe: Lipodistrofia. Perfil bioquímico. HIV. 


\section{REFERENCES}

1. UNAIDS/2018-Joint United Nations Programme on HIV/AIDS. Report on the globalAIDS Epidemic - Overview of the global AIDS Epidemic [Internet]. 2018. State of the Epidemic. [cited 20184 de dezembro]. Available from: URL:http://www.unaids.org/en/resources/documents/2018/unaidsdata 2018.

2. Teeraananchai S, Kerr S|, Amin |, Ruxrungtham K, Law MG. Life expectancy of HIV-positive people after starting combination antiretroviral therapy: a meta-analysis. HIV Med. 2017;18(4):256-66.

3. Pires DS, Ferraz SF, Monteiro ML, Reis VAGA, Pontes DB, Andrade MIVAMCN. Perfil nutricional e métodos de avaliação do estado nutricional de pacientes infectados pelo HIV. BRASPEN J. 2017;32(3):209-13.

4. Strategies for Management of Antiretroviral Therapy (SMART) Study Group, Emery S, Neuhaus JA, Phillips AN, Babiker A, Cohen C), Gatell JM, et al. Major clinical outcomes in antiretroviral therapy (ART)-naive participants and in those not receiving ART at baseline in the SMART study. Infect Dis. 2008;197(8):1133-44.

5. Soares LR. Perfil antropométrico e correlação entre diferentes medidas relativas à composição corporal e a distribuição da gordura relacionados ao risco cardiovascular em indivíduos adultos vivendo com HIV/AIDS [dissertação]. São Paulo: Faculdade de Medicina, Universidade de São Paulo; 2010. 116p.

6. Brasil. Ministério da Saúde. Secretaria de Atenção à Saúde. Departamento de Atenção Básica. HIV/AIDS, hepatites e outras DST. Protocolo clínico e diretrizes terapêuticas para adultos vivendo com HIV/AIDS. Brasília: Ministério da Saúde; 2018.

7. Faludi AA, Izar MCO, Saraiva JFK, Chacra APM, Bianco HT, Afiune Neto $A$, et al. Atualização da diretriz brasileira de dislipidemias e prevenção da aterosclerose-2017. Arq Bras Cardiol. 2017;109(2):1-76.

8. Sociedade Brasileira de Diabetes. Diretrizes da Sociedade Brasileira de Diabetes 2017/2018. Grupo Gen-AC Farmacêutica. São Paulo: Clannad; 2017.

9. Obesity: preventing and managing the global epidemic. Report of a WHO consultation. World Health Organ Tech Rep Ser. 2000;894:i-xii, 1-253.

10. National Institutes of Health et al. The Practical guide: identification, evaluation, and treatment of overweight and obesity in adults. NIH Publication Number 00-4084. [cited 2019 Jul 21]. Available from: https://www.nhlbi. nih.gov/files/docs/guidelines/prctgd_c.pdf

11. Ashwell M, Hsieh SD. Six reasons why the waist-to-height ratio is a rapid and effective global indicator for health risks of obesity and how its use could simplify the international public health message on obesity. Int J Food Sci Nutr. 2005;56(5):303-7.

12. Ben-Noun L, Laor A. Relationship of neck circumference to cardiovascular risk factors. Obes Res. 2003;11(2):226-31.
13. Schutz $Y$, Kyle UU, Pichard C. Fat-free mass index and fat mass index percentiles in Caucasians aged 18-98 y. Int | Obes Relat Metab Disord. 2002;26(7):953-60.

14. Durnin JV, Womersley J. Body fat assessed from total body density and its estimation from skinfold thickness: measurements on 481 men and women aged from 16 to 72 years. Br J Nutr. 1974;32(1):77-97.

15. Lohman TG. Advances in body composition assessment: current issues in exercise science. Monograph 3. Champaign: Human Kinetics Publishers; 1992.

16. Frisancho AR. Anthropometric standards for the assessment of growth and nutritional status. Ann Arbor: University of Michigan Press; 1990.

17. Lee RC, Wang Z, Heo M, Ross R, Janssen I, Heymsfield SB. Total-body skeletal muscle mass: development and cross-validation of anthropometric prediction models. Am J Clin Nutr. 2000;72(3):796-803.

18. Erlandson KM, Campbell TB. Inflammation in chronic HIV infection: what can we do? I Infect Dis. 2015;212(3):339-42.

19. Marins GO, Cardoso TLSR, Soares LR, Almeida KCL. Alterações bioquímicas em pessoas com HIV/AIDS no Município de Macaé, Rio de Janeiro, Brasil. Acta Brasiliensis. 2018;2(3):80-3.

20. Iwuala SO, Lesi OA, Fasanmade OA, Sabir AA, Olamoyegun MA, Okany CC. Prevalence of and risk factors for lipoatrophy in patients with HIV infection in Nigeria. AIDS Res Treat. 2015;2015:402638.

21. Beraldo RA, Meliscki GC, Silva BR, Navarro AM, Bollela VR, Schmidt A, et al. Anthropometric measures of central adiposity are highly concordant with predictors of cardiovascular disease risk in HIV patients. Am J Clin Nutr. 2018;107(6):883-93.

22. Sacilotto LB, Pereira PCM, Manechini IPV, Papini S|. Body composition and metabolic syndrome components on lipodystrophy different subtypes associated with HIV. I Nutr Metabol. 2017. [cited 2019 Feb 21]. Available from: http://downloads.hindawi.com/journals/jnme/2017/8260867.pdf

23. Santos AP, Navarro AM, Schwingel A, Alves TC, Abdalla PP, Venturini AC, et al. Lipodystrophy diagnosis in people living with HIV/AIDS: prediction and validation of sex-specific anthropometric models. BMC Public Health. 2018;18(1):806

24. Alencastro PR, Barcellos NT, Wolff FH, Ikeda ML, Schuelter-Trevisol $F$, Brandão $A B$, et al. People living with HIV on ART have accurate perception of lipodystrophy signs: a cross-sectional study. BMC Res Notes. 2017;10(1):40. 